In Situ

In Situ

Revue des patrimoines

Revue des patrimoines

18 | 2012

Le cheval et ses patrimoines (1ère partie)

\title{
« Film : Pompadour, c'est la volonté »
}

\section{Cécile Coste}

\section{OpenEdition}

\section{Journals}

Édition électronique

URL : http://journals.openedition.org/insitu/9756

DOI : $10.4000 /$ insitu.9756

ISSN : 1630-7305

\section{Éditeur}

Ministère de la culture

\section{Référence électronique}

Cécile Coste, « «Film : Pompadour, c'est la volonté » », In Situ [En ligne], 18| 2012, mis en ligne le 04 septembre 2012, consulté le 23 avril 2019. URL : http://journals.openedition.org/insitu/9756 ; DOI 10.4000/insitu.9756

Ce document a été généré automatiquement le 23 avril 2019

\section{(c) (i) $\odot$}

In Situ Revues des patrimoines est mis à disposition selon les termes de la licence Creative Commons Attribution - Pas d'Utilisation Commerciale - Pas de Modification 4.0 International. 


\section{" Film : Pompadour, c'est la volonté »}

\section{Cécile Coste}

1 Film : co-production du Conseil général de Corrèze et du Haras National de Pompadour

2 Réalisation : CG19 - direction de la communication du Conseil général

3 Réalisé dans le cadre du colloque «Le cheval et ses patrimoines» (juin 2011), ce film témoigne de l'ancrage territorial de la «culture cheval » sur ce site emblématique des Haras nationaux qu'est Pompadour.

4 Cette culture autour du cheval se perçoit à travers des patrimoines bâtis et paysagers remarquables qu'acteurs locaux et collectivités s'emploient à préserver et valoriser.

5 Elle se prolonge par une tradition équestre qui a su s'adapter à l'évolution du rôle du cheval dans la société (du cheval de guerre au cheval loisir), comme à l'évolution des missions des haras à travers le temps. De haras royal, Pompadour est en effet devenu un haut lieu de manifestations sportives équestres nationales comme internationales.

6 Voir le site: http://www.culturecommunication.gouv.fr/Politiques-ministerielles/ Connaissances-des-patrimoines-et-de-l-architecture/Colloques-et-journees-d-etudes/Lecheval-et-ses-patrimoines/Le-cheval-et-ses-patrimoines-Tulle-15-17-juin-2011

\section{AUTEUR}

CÉCILE COSTE

Conseil général de Corrèze ccoste@cg19.fr 